\title{
Analisis Pengaruh Citra Merek, Kualitas Produk dan Harga terhadap Perpindahan Merek (Studi Kasus pada Produk Oriflame di Kota Langsa)
}

\author{
Rahmi Meutia \\ Fakultas Ekonomi Universitas Samudra \\ e-mail: rahmi.meutia@unsam.ac.id
}

\begin{abstract}
Abstrak
Penelitian ini bertujuan untuk mengetahui pengaruh citra merek, kualitas produk dan harga terhadap keputusan perpindahan merek oriflamme di kota langsa. Penelitian ini dilakukan terhadap konsumen yang sebelumnya tidak memakai oriflamme kemudian berpindah menggunakan oriflamme. Persamaan regresi dalam penelitian ini adalah $Y=2,183+0,152 X_{1}+0,323 X_{2}+0,009 X_{3}$. Hasil uji $t$ menunjukkan secara parsial hanya variabel kualitas produk yang memiliki pengaruh signifikan terhadap perpindahan merek. Hasil uji $F$ menunjukkan bahwa secara simultan variabel bebas mempunyai pengaruh signifikan terhadap perpindahan merek. Nilai Adjusted $R$ square didapat sebesar $8 \%$, sedangkan sisanya sebesar $92 \%$ dijelaskan oleh variabel-variabel lain yang tidak termasuk dalam penelitian ini.
\end{abstract}

Kata Kunci: Citra Merek, Kualitas Produk, Harga, Perpindahan Merek

\section{PENDAHULUAN}

Persaingan antar pasar industri perawatan pribadi dan kosmetik semakin kompetitif. Hal ini terbukti dengan banyaknya jenis kosmetika beredar baik produksi dalam negeri maupun produksi luar negeri. Membanjirnya produk kosmetika di pasaran mempengaruhi sikap seseorang terhadap pemakaian barang. Banyak merek kosmetik yang beredar di pasaran, sehingga menjadi pertimbangan bagi konsumen untuk memilih salah satu merek yang dianggap tepat. Tiap-tiap merek produk kosmetik memiliki keunggulan dan ciri-ciri tersendiri yang membedakan dari produk pesaing sejenis. Oleh karena itu, konsumen saat ini dituntut untuk dapat memilih secara selektif dari alternatif pilihan-pilihan merek yang dihasilkan oleh berbagai produsen kosmetik. Apabila konsumen tidak jeli, dan tidak memperhatikan kandungan komposisi produknya, maka kandungan bahan berbahaya dapat menganggu kesehatan.

Citra merek (Brand image) adalah persepsi tentang suatu merek yang terekam dalam memori konsumen. Seiring dengan berkembangnya zaman maka semakin banyak pula merek-merek yang menghasilkan produk yang sama. Dengan banyaknya merek yang ada, hal itu dapat menyebabkan konsumen berpindah dari satu merek ke merek lainnya. Melihat adanya fenomena tersebut, perusahaan seharusnya dapat memenuhi apa yang dibutuhkan dan diharapkan dari konsumen.

Permintaan akan sebuah produk barang yang semakin berkualitas membuat perusahaan berlomba-lomba meningkatkan kualitas produk dan mempertahankan citra merek produk yang mereka miliki. Kualitas produk adalah kecocokan penggunaan produk untuk memenuhi kebutuhan dan kepuasan pelanggan. Adapun tujuan dari kualitas produk adalah mengusahakan barang hasil produksi dapat mencapai standar yang telah ditetapkan, mengusahakan agar biaya desain dari produksi tertentu menjadi sekecil mungkin, dan mengusahakan agar biaya produksi dapat menjadi serendah mungkin. 
Produk yang memiliki tingkat kualitas yang dinamis akan mengurangi risiko terjadinya brand switching. Persepsi harga merupakan sebuah bahan pertimbangan yang penting dalam membeli sebuah produk karena harga merupakan salah satu faktor penentu. Harga ialah jumlah nilai yang konsumen keluarkan untuk mendapatkan barang atau jasa. Perpindahan merek juga dapat terjadi saat tingkat kepuasan konsumen rendah. Beragamnya produk mengakibatkan konsumen sedikit banyak mempunyai keinginan untuk berpindah dari merek lain ke merek oriflame.

Perpindahan merek merupakan gambaran dari beralihnya pengkonsumsian konsumen atas suatu produk ke produk lainnya. Oriflame menyediakan semua alat penunjang tata rias baik lipgloss, lipstick, bedak, mascara, dan lain-lain yang dibutuhkan demi menunjang penampilan di kehidupan sosial. Ukuran yang menjadi pertimbangan konsumen ialah merek harus memiliki kesan positif dan mudah dikenali, kualitas menyatakan tingkat kemampuan suatu produk dalam mencapai posisi tertinggi, apabila harga yang ditawarkan tidak sesuai dengan citra merek dan kualitas produk maka hal ini dapat memicu konsumen untuk berpindah ke merek lain.

Tujuan yang hendak penulis capai dalam penelitian ini adalah:

1. Untuk mengetahui pengaruh citra merek, kualitas produk, dan harga secara parsial terhadap perpindahan merek pada produk oriflame.

2. Untuk mengetahui pengaruh citra merek, kualitas produk, dan harga secara simultan terhadap perpindahan merek pada produk oriflame.

\section{Citra Merek}

Definisi citra merek menurut Dinawan (2010), yaitu konsumen cenderung membeli merek yang sudah dikenal karena mereka merasa aman dengan sesuatu yang dikenal an beranggapan merek yang sudah dikenal tersebut kemungkinan bisa diandalkan dan kualitasnya dapat dipertanggungjawabkan. Sedangkan menurut Ferrinadewi (2008) menyebutkan bahwa brand image adalah persepsi tentang merek yang merupakan refleksi memori konsumen akan asosiasinya pada merek tersebut. Citra merek merupakan asosiasi dari semua informasi yang tersedia mengenai produk, jasa dan perusahaan dari merek yang dimaksud (Ratri, 2007).

\section{Fa k t or -f ak t o r Citra Merek (Brand Image)}

Pada perkembangan perekonomian saat ini merek menjadi sangat penting. Menurut Durianto (2008), hal ini disebabkan oleh beberapa faktor, antara lain:

1. Emosi konsumen terkadang turun naik. Merek mampu membuat janji emosi menjadi konsisten dan stabil.

2. Merek mampu menembus setiap pagar budaya dan pasar. Bisa dilihat bahwa suatu merek yang kuat dapat diterima oleh seluruh dunia dan budaya.

3. Merek mampu menciptakan komunikasi interaksi dengan konsumen.

Semakin kuat suatu merek, makin kuat pula interaksinya dengan konsumen. Akibatnya, semakin banyak asosiasi merek yang terbentuk dalam merek tersebut. Jika asosiasi merek terbentuk memiliki kualitas dan kuantitas yang kuat, potensi ini akan meningkatkan citra merek dari produk yang bersangkutan.

4. Merek sangat berpengaruh dalam membentuk perilaku konsumen. Merek yang kuat akan mampu mengubah perilaku konsumen.

5. Merek memudahkan proses pengambilan keputusan pembelian oleh konsumen. Merek berkembang menjadi sumber asset terbesar bagi perusahaan dan merek juga digunakan untuk beberapa tujuan yaitu:

a. Sebagai identitas, yang bermanfaat dalam diferensi atau membedakan produk suatu perusahaan dengan produk pesaingnya. Ini memudahkan konsumen untuk mengenalinya saat berbelanja dan saat melakukan pembelian ulang. 
b. Alat promosi, yaitu sebagai daya tarik produk.

c. Untuk membina citra, yaitu dengan memberikan keyakinan, jaminan kualitas kepada konsumen.

d. Untuk mengendalikan pasar.

Melalui citra merek yang baik, maka konsumen atau pelanggan akan memiliki asumsi positif terhadap merek dari produk yang ditawarkan oleh perusahaan. Melalui citra merek yang baik akan timbul perasaan positif pada saaat membeli atau menggunkan merek tertentu. Demikian pula sebaliknya, apabila suatu merek memiliki citra yang buruk maka konsumen atau pelanggan akan memiliki asumsi negatif terhadap merek dari produk yang ditawarkan oleh perusahaan sehingga kemungkinan konsumen membeli produk tersebut semakin kecil.

\section{Manfaat Citra Merek}

Menurut Sutisna (2013), ada beberapa manfaat pentingnya citra merek. Manfaatmanfaat tersebut dikemukakan sebagai berikut:

1. Konsumen dengan citra yang positif terhadap suatu merek, lebih memungkinkan untuk melakukan pembelian;

2. Perusahaan dan mengembangkan lini produk dengan memanfaatkan citra positif yang telah terbentuk terhadap merek produk yang lama;

3. Kebijakan family branding dan laverage branding dapat dilakukan jika citra merek produk yang telah ada positif.

\section{Indikator Citra Merek}

Sunyoto (2012) menjelaskan indikator citra merek, yaitu sebagai berikut:

1. Mudah dibaca, diucapkan dan diingat.

2. Singkat dan sederhana.

3. Mempunyai ciri khas tersendiri dan disenangi oleh konsumen.

4. Merek harus menggambarkan kualitas, prestise, produk dan sebagainya.

5. Bisa diadaptasi oleh produk-produk baru yang mungkin ditambahkan di lini produk.

6. Merek harus dapat didaftarkan dan mempunyai perlindungan hukum.

\section{Kualitas Produk}

Menurut Alma (2007), kualitas produk adalah keseluruhan gabungan karakteristik barang dan jasa dari pemasaran, rekayasa, pembuatan dan pemeliharaan yang membuat produk dan jasa yang digunakan memenuhi harapan pelanggan. Juran (2011) menyatakan bahwa kualitas produk adalah kecocokan penggunaan produk untuk memenuhi kebutuhan dan kepuasan pelanggan. Sedangkan menurut Hadi (2006), kualitas produk adalah yang paling utama dari suatu produk, biasanya berkaitan dengan fungsi kegunaan produk tersebut. Konsumen akan menyukai produk yang menawarkan kualitas, kinerja, dan pelengkap inovatif yang terbaik.

\section{Faktor-faktor Kualitas Produk}

Menurut Nurhayati (2011), dalam hal mutu suatu produk yang dihasilkan oleh suatu perusahaan kadang mengalami keragaman. Hal ini disebabkan mutu suatu produk itu dipengaruhi oleh beberapa faktor, antar lain:

\section{Manusia}

Peranan manusia atau karyawan yang bertugas dalam perusahaan akan sangat mempengaruhi secara langsung terhadap baik buruknya mutu dari produk yang dihasilkan oleh suatu perusahaan.

2. Manajemen

Tangung jawab atas mutu produk dalam perusahaan dibebankan kepada beberapa kelompok yang biasa disebut dengan function group.

3. Uang

Perusahaan harus menyediakan uang yang cukup untuk mempertahankan atau meningkatkan mutu produksinya.

4. Bahan baku

Bahan baku merupakan salah satu faktor yang sangat penting dan akan mempengaruhi terhadap mutu produk yang dihasilkan oleh suatu perusahaan.

5. Mesin dan Peralatan

Mesin serta peralatan yang sering digunakan dalam proses produksi akan 
mempengaruhi terhadap mutu produk yang dihasilkan perusahaan.

\section{Dimensi Kualitas Produk}

Alma (2011) menyatakan bahwa dimensi-dimensi kualitas produk terdiri dari:

1. Kinerja (performance), yaitu karakteristik operasi pokok dari produk inti.

2. Ciri-ciri atau keistimewaan tambahan (features), yaitu karakteristik sekunder atau pelengkap.

3. Kehandalan (reliability), yaitu kemungkinan kecil akan mengalami kerusakan atau gagal pakai.

4. Kesesuaian dengan spesifikasi (conformance to specification), yaitu sejauh mana karakteristik desain dan operasi memenuhi standar-standar yang telah ditetapkan sebelumnya.

5. Daya tahan (durability), yaitu berkaitan dengan berapa lama produk tersebut dapat terus digunakan.

6. Serviceability, meliputi kecepatan, kompetensi, kenyamanan, mudah direparasi, penanganan keluhan yang memuaskan.

7. Estetika, yaitu daya tarik produk terhadap panca indera.

\section{Harga}

Menurut Dinawan (2010), harga dari sudut pandang pemasaran merupakan suatu moneter atau ukuran lainnya (termasuk barang dan jasa lainnya) yang ditukarkan agar memperoleh hak kepemilikan atau penggunaan suatu barang dan jasa. Sedangkan menurut Kotler dan Keller (2009) harga adalah salah satu elemen bauran pemasaran yang menghasilkan pendapatan, elemen lain menghasilkan biaya, harga merupakan elemen termudah dalam program pemasaran untuk disesuaikan, fitur produk, saluran, dan bahkan komunikasi membutuhkan banyak waktu.

\section{Faktor- faktor yang Mempengaruhi Tingkat Harga}

Dalam kenyataan, tingkat harga barang dan jasa dapat dipengaruhi oleh beberapa faktor. Adapun faktor-faktor yang dapat mempengaruhi tingkat harga menurut Sinaga (2010) yaitu:

1. Keadaan perekonomian.

2. Penawaran dan permintaan.

3. Elastisitas permintaan.

4. Persaingan.

5. Biaya.

6. Tujuan Manager.

7. Pengawasan Pemerintah.

\section{Indikator Harga}

Menurut Stanton \& William (2009), indikator harga yaitu:

1. keterjangkauan harga produk

2. kesesuaian harga dengan kualitas produk

3. daya saing produk

4. kesesuaian dengan manfaat produk

\section{Perpindaham Merek}

Menurut Swastha (2011), Brand switching behavior sebagai perilaku perpindahan merek yangdilakukan oleh konsumen karena alasan tertentu atau dapat diartikan juga sebagai kerentanan konsumen untuk berpindah ke merek lain. Perilaku ini dapat juga terjadi karena adanya masalah yang ditemukan atas produk yang sudah dibeli (Widyasari, 2008). Perilaku perpindahan merek ini sebagai salah satu perilaku pembelian suatu produk dengan merek yang berbeda dari merek favorit yang biasa dibeli oleh konsumen. Perpindahan merek dapat terjadi karena adanya promosi harga, in store displays, ketersediaan, inovasi, hasrat pada sesuatu yang baru, risiko, perubahan kualitas, ataupun tingkat kepuasan (Goswami, 2008).

\section{Indikator Perpindahan Merek}

Indikator perpindahan merek (Yayan, 2016) yaitu:

1. Kualitas Produk

2. Merek

3. Desain

4. Fitur Produk

5. Harga

6. Munculnya produk baru

7. Promosi penjualan

8. Distribusi 


\section{Hipotesis}

Berdasarkan latar belakang penelitian dan tujuan penelitian diduga bahwa:

1. Citra merek, Kualitas produk, dan Harga secara parsial berpengaruh signifikan terhadap perpindahan merek oriflame di Kota Langsa.

2. Citra merek, Kualitas produk, dan Harga secara simultan berpengaruh signifikan terhadap perpindahan merek oriflame di Kota Langsa.

\section{METODE PENELITIAN \\ Jenis dan Sumber Data}

Jenis data yang digunakan dalam penelitian ini adalah:

1. Data kualitatif yaitu jenis data yang digunakan untuk mendapatkan data yang mendalam yang mengandung makna. Oleh karena itu dalam penelitian kualitatif tidak menekankan pada generalisasi, tetapi lebih menekankan pada makna (Sugiyono, 2008). Dalam penelitian ini, data kualitatif berupa teori-teori dari pendapat ahli dan gambaran umum Oriflame.

2. Data kuantitatif yaitu jenis data yang berupa angka-angka dan analisis menggunakan statistik (Sugiyono, 2008). Dalam penelitian ini, data kuantitatif berupa hasil skor kuesioner kepada responden yang diklasifikasikan dengan menggunakan Skala Likert (1-5).

Adapun sumber data yang akan digunakan dalam penelitian ini adalah:

1. Data primer yaitu sumber data yang langsung memberikan data kepada pengumpul data (Sugiyono, 2014). Data primer dalam penelitian ini berupa hasil observasi, wawancara, dan penyebaran kuesioner kepada responden.

2. Data sekunder yaitu sumber data yang tidak secara langsung memberikan data kepada pengumpul data, misalnya lewat orang lain atau dokumen (Sugiyono, 2014). Data sekunder dalam penelitian ini berupa artikel-artikel jurnal, buku-buku referensi, skripsi dan internet yang ada kaitannya dengan penelitian ini.

\section{Metode Pengumpulan Data}

Teknik pengumpulan data yang digunakan dalam penelitian ini adalah:

1. Penelitian Lapangan (Field Research), meliputi:

a. Observasi merupakan metode pengumpulan data yang digunakan untuk menghimpun data penelitian melalui pengamatan dan pengindraan (Bungin, 2007).

b. Wawancara, wawancara dilakukan sebagai teknik pengumpulan data, apabila peneliti ingin melakukan studi pendahuluan untuk menemukan permasalahan yang harus diteliti, dan juga apabila peneliti ingin mengetahui hal-hal yang lebih mendalam (Sugiyono, 2008). Dalam wawancara ini peneliti melakukan wawancara kepada konsumen Oriflame di Kota Langsa untuk menggali informasi yang dapat membantu meningkatkan hasil dari penelitian ini.

c. Angket/kuesioner merupakan metode pengumpulan data melalui penyebaran daftar pertanyaan yang diajukan sehubungan dengan materi penelitian kepada responden yang telah terpilih untuk dijawab (Sugiyono, 2009).

2. Penelitian Kepustakaan

Teknik pengumpulan data dengan mengadakan studi penelaahan terhadap buku-buku, literatur-literatur, catatancatatan dan laporan-laporan yang ada hubungannya dengan masalah yang diteliti.

\section{Populasi dan Sampel}

Menurut Morissan (2012), populasi dapat didefinisikan sebagai suatu kumpulan subjek, variabel, konsep, atau fenomena. Kita dapat meneliti setiap anggota populasi untuk mengetahui sifat populasi yang bersangkutan. Populasi dalam penelitian ini adalah konsumen yang melakukan perpindahan dari merek lain ke merek oriflame yang berlokasi di Kota Langsa yang jumlahnya tidak diketahui 
secara pasti. Sampel (sample) adalah bagian dari populasi yang sengaja dipilih oleh peneliti untuk diamati, sehingga sampel ukurannya lebih kecil dibandingkan populasi dan berfungsi sebagai wakil dari populasi (Nurhayati, 2012). Dikarenakan jumlah populasinya tidak diketahui secara pasti jumlahnya maka untuk menentukan jumlah sampel digunakan rumus Uknown Population sebagai berikut (Prasetya, 2011)

Keterangan:

$$
n=\left[\frac{Z a / 2 \sigma}{e}\right]^{2}
$$

n : jumlah sampel

$\mathrm{Za}$ : ukuran tingkat kepercayaan dengan $\alpha=0,05$

$\sigma \quad:$ standar deviasi

e : standar error

Dengan menggunakan rumus tersebut didapat jumlah minimum sampel dalam penelitian ini adalah 96 orang, jumlah sampel yang digunakan dalam penelitian ini 100 orang. Teknik pengambilan sampel pada penelitian ini menggunakan teknik purposive sampling yaitu teknik pengambilan sampel sumber data dengan pertimbangan tertentu. Kriteria yang dapat dijadikan sebagai sampel dalam penelitian ini adalah individu yang menggunakan produk Oriflame dan diharapkan dapat menjawab dengan baik pertanyaan/kuesioner yang diajukan.

\section{Metode Analisis Data}

Metode analisis data yang digunakan dalam penelitian ini adalah analisis regresi linear berganda. Analisis regresi linear berganda digunakan untuk mengetahui pengaruh antara lebih dari satu variabel bebas terhadap variabel terikat. Model hubungan variabel-variabel dalam penelitian ini dapat disusun dalam fungsi atau persamaan sebagai berikut (Sugiyono, 2012):

$$
y=\alpha+\beta_{l} X_{l}+\beta_{2} X_{2}+\beta_{3} X_{3}+e
$$

Keterangan:

$$
\begin{aligned}
& Y= \\
& \text { Verpindahan Merek, Sebagai } \\
& \text { Variabel Dependen }
\end{aligned}
$$

$$
\begin{aligned}
& \alpha=\text { Konstanta } \\
& \beta l, \beta_{2}, \beta_{3} \quad=\text { Koefisien Regresi } \\
& X_{l} \quad=\text { Citra Merek, Sebagai Variabel } \\
& \text { Independen } \\
& X 2=\text { Kualitas Produk, Sebagai } \\
& \text { Variabel Independen } \\
& \text { X3 = Harga, Sebagai Variabel } \\
& \text { Independen } \\
& e \quad=\text { Error } / \text { Variabel Pengganggu }
\end{aligned}
$$

\section{HASIL ANALISIS}

Hasil penelitian dapat dilihat pada table 1. Berdasarkan tabel 1 maka dapat dibuat persamaan sebagai berikut:

$$
\mathrm{Y}=2,183+0,152 \mathrm{X}_{1}+0,323 \mathrm{X}_{2}+0,009 \mathrm{X}_{3}
$$

Dari persamaan tersebut dapat dijelaskan bahwa:

1. Nilai konstanta memiliki nilai yang positif sebesar 2,183, hal ini berarti bahwa jika nilai variabel citra merek, kualitas produk dan harga di anggap tetap dan bernilai nol, maka perpindahan merek masih memiliki nilai positif.

2. Nilai unstandardized coefficients (B) untuk variabel $\mathrm{X}_{1}$ (citra merek) yang bernilai positif sebesar 0,152 menunjukkan bahwa terdapat pengaruh yang positif antara variabel citra merek dengan perpindahan merek, jadi jika variabel citra merek pada suatu merek meningkat maka perpindahan merek dari merek yang sering digunakan ke merek oriflame juga akan meningkat.

Nilai unstandardized coefficients (B) untuk variabel $\mathrm{X}_{2}$ (kualitas produk) yang bernilai positif sebesar 0,323 menunjukkan bahwa terdapat pengaruh yang positif antara variabel kualitas produk dengan perpindahan merek, jadi jika variabel kualitas produk pada suatu merek meningkat maka perpindahan merek dari merek yang sering digunakan ke merek oriflame juga akan meningkat.

3. Nilai unstandardized coefficients (B) untuk variabel $\mathrm{X}_{3}$ (harga) yang bernilai positif sebesar 0,009 menunjukkan 
Tabel 1. Hasil Analisis Statistik

\begin{tabular}{|c|c|c|c|}
\hline Variabel & $\mathrm{B}$ & $\mathrm{t}$ & Sig.t \\
\hline Kostanta & 2,183 & 2,875 & 0,005 \\
\hline Citra Merek & 0,152 & 1,277 & 0,205 \\
\hline Kualitas Produk & 0,323 & 2,749 & 0,007 \\
\hline Harga & 0,009 & 0,079 & 0,937 \\
\hline Adjusted R. Square & 0,088 & & \\
\hline $\mathrm{F}$ & 4,168 & & \\
\hline Sig. F & 0,008 & & \\
\hline
\end{tabular}

Sumber: Data Primer diolah, 2017

bahwa terdapat pengaruh yang positif antara variabel harga dengan perpindahan merek, jadi jika variabel harga pada suatu merek meningkat maka perpindahan merek dari mereka yang sering digunakan ke merek oriflame juga akan meningkat.

\section{Koefisien Determinasi $\left(\mathbf{R}^{2}\right)$}

Dari hasil analisis tampak bahwa nilai Adjusted $\mathrm{R}$ Square sebesar 0,088. Interpretasinya adalah bahwa variabelvariabel independen yang digunakan dalam model penelitian ini memberi kontribusi sebesar $8 \%$. Untuk menjelaskan variabelvariabel terhadap perpindahan merek di Kota Langsa sedangkan sisanya sebesar $92 \%$ $(=100 \%-8 \%)$ dijelaskan oleh variabelvariabel lain yang tidak termasuk dalam model penelitian ini.

\section{Pembuktian Hipotesis Uji t (Uji Parsial)}

Untuk mengetahui apakah masingmasing variabel independent (yaitu: citra merek (X1), kualitas produk (X2), dan harga (X3)) secara parsial mempunyai pengaruh yang signifikan atau tidak signifikan terhadap variabel dependen (perpindahan merek (Y)), maka digunakan uji $\mathrm{t}(\mathrm{t}$-test) dua arah (two side atau 2-tail test) dengan cara membandingkan nilai signifikansinya dengan $\alpha$, dengan derajat kebebasan (degree of freedom) sebesar $95 \% \quad(\alpha=5 \%)$. Kriteria pengujiannya adalah jika Sig. $\mathrm{t}>\alpha(0,05)$ maka H1 ditolak dan H1 diterima, jika Sig. $\mathrm{t}<\alpha(0,05)$ maka hipotesis penerlitian diterima. Berdasarkan hasil analisis dapat dirangkum:
1. Variabel citra merek (X1) memiliki nilai $\mathrm{t}$ sebesar 1,277 dengan Sig. Sebesar 0,205. Karena nilai Sig. $t>\alpha$ $(0,05)$ berarti variabel citra merek mempunyai pengaruh tidak signifikan terhadap perpindahan merek oriflame di Kota Langsa.

2. Variabel Kualitas Produk (X2) memiliki nilai $\mathrm{t}$ sebesar 2,749 dengan Sig. sebesar 0,007. Karena nilai Sig. $\mathrm{t}<$ $\alpha(0,05)$ berarti variabel Kualitas Produk mempunyai pengaruh signifikan terhadap perpindahan merek oriflame di Kota Langsa.

3. Variabel harga $\left(\mathrm{X}_{3}\right)$ memiliki nilai $\mathrm{t}$ sebesar 0,079 dengan Sig. Sebesar 0,937 . Karena nilai Sig. $t>\alpha(0,05)$ berarti variabel harga mempunyai pengaruh tidak signifikan terhadap perpindahan merek oriflame di Kota Langsa.

\section{Uji F (Uji Simultan)}

Untuk mengetahui apakah variabelvariabel independen secara simultan (bersama-sama) mempunyai mempunyai pengaruh yang signifikan atau tidak signifikan terhadap variabel dependen maka digunakan uji $\mathrm{F}$ ( $F$ test) yaitu dengan cara membandingkan nilai signifikannya dengan $\alpha$. Kriteria pengujiannya adalah jika Sig. F> $\alpha(0,05)$ maka $\mathrm{H} 2$ ditolak dan $\mathrm{H} 2$ diterima, jika Sig. $\mathrm{F}<\quad \alpha \quad(0,05)$ maka hipotesis penelitian diterima. Berdasarkan hasil analisis dapat dirangkum bahwa model penelitian ini memiliki nilai $\mathrm{F}$ sebesar 4,168 dengan Sig. sebesar 0,008. Karena nilai Sig. $\mathrm{F}<\alpha(0,05)$ sehingga dapat dinyatakan bahwa variabel-variabel independen yang 
meliputi citra merek (X1), kualitas produk (X2), dan harga (X3) mempunyai pengaruh simultan yang signifikan terhadap perpindahan merek oriflame di Kota Langsa. Dengan demikian, Hipotesis 2 bisa diterima atau dibuktikan kebenarannya.

\section{KESIMPULAN}

Berdasarkan hasil penelitian yang telah diuraikan sebelumnya, maka dapat ditarik beberapa kesimpulan sebagai berikut:

1. Hasil analisis regresi linier berganda menunjukkan nilai standardized coefficients (Beta) yang menyatakan bahwa variabel independen yang paling besar pengaruhnya terhadap perpindahan merek adalah kualitas produk, citra merek, dan harga.

2. Hasil Uji t menunjukkan bahwa hanya variabel kualitas produk yang memiliki pengaruh parsial yang signifikan terhadap perpindahan merek oriflame di Kota Langsa.

3. Hasil Uji F bahwa variabel-variabel independen yang meliputi citra merek, kualitas produk dan harga mempunyai pengaruh simultan yang signifikan terhadap perpindahan merek oriflame di Kota Langsa

\section{DAFTAR PUSTAKA}

Arikunto, S. 2010. Prosedur Penelitian: Suatu Pendekatan Praktik. Jakarta: Rineka Cipta.

Ghozali, Imam. 2011. Aplikasi Multivarariate dengan Program SPSS. Semarang: Badan Penerbit Universitas Diponegoro.

Hadi, S. 2006. Metodologi Research. Jilid I. Yogyakarta: Andi Offset.

Hawkins, D.I., dan Motherbaugh, D.L. 2010. Consumer Behavior: Building Marketing Strategy. 11 th edition. McGraw-Hill, Irwin

\section{Herlambang, 2014. Basic Marketing} (Dasar-Dasar Pemasaran). Yogyakarta: Gosyen Publishing.
Husein, Umar. 2008. Metode Penelitian Untuk Skripsi dan Tesis Bisnis. Jakarta: PT. Rajagrafindo Persada.

Kotler \& Keller. 2009. Manajemen Pemasaran. Jakarta: Erlangga 2007. Manajemen

Pemasaran. Jakarta: PT Indek. Morissan. 2012. Periklanan Komunikasi Pemasaran Terpadu. Jakarta: Kencana.

Rangkuti Freddy. 2009. Strategi Promosi Kreatif dan Analisis Kasus Integratet Marketing Communication. Jakarta: Gramedia Pustaka Utama. 